\title{
Some Growth Characteristics of Four Old World Bluestems
}

\author{
P.I. COYNE AND J.A. BRADFORD
}

The growth dynamics of 4 Old World bluestem (Bothriochloa spp.) accessions were monitored in the field by periodic harvests of the aboveground biomass components (leaf blades, leaf sheaths plus enclosed stems, exerted stems plus inflorescences) during 2 growth cycles from April to September 1982. The first cycle extended from spring growth initiation (15 March) through flowering ( 6 July). The second cycle was initiated following the completion of the first by mowing the plants to a $50-\mathrm{mm}$ stubble height and ended at flowering stage (20 September). Growth conditions during the first cycle were considered near optimum when precipitation was 1.71 of the long term mean and soil moisture averaged about 0.29 by volume. Temperatures during the second cycle were approximately $10^{\circ} \mathrm{C}$ higher than during the first and precipitation was only 0.18 of normal. Soil moisture declined linearly throughout the second cycle and all accessions exhibited visual symptoms of drought stress. There were significant differences among accessions for most of the experimental parameters and accession ranking changed with the imposition of drought stress during the second cycle. Accessions with high relative growth rates were least tolerant of drought stress. Severe defoliation by clipping at the start of cycle 2 revealed 2 regrowth patterns which suggested potential differences in grazing tolerance. Two accessions tended to optimize canopy development by maximizing leaf area index while minimizing biomass and nitrogen investment per unit leaf area. The remaining 2 accessions produced fewer leaves with more investment per leaf. Lower relative growth rates of biomass and the ability to optimize canopy development following defoliation may result in a more stable forage source through time. Plants with these characteristics may not be top producers during periods of favorable growing conditions, but will likely maintain a level of performance under stress which compares more favorably with pre-stress performance.

The Old World bluestems (OWB, Bothriochloa spp.) are indigenous to much of Europe and Asia. This group of warm-season grasses possesses the $\mathrm{C} 4$ photosynthetic pathway (Waller and Lewis 1979) and most are highly apomictic in their reproductive behavior (Harlan et al. 1964).

Celarier and Harlan (1955) reported that the earliest recorded introductions of the OWB's to the Western Hemisphere and to the United States were in 1894 and 1917 , respectively. They point out that interest in these grasses resulted from their apparent superiority to American forms (Andropogon spp.) with respect to quality, production, persistence under grazing, and ability to respond to high fertility levels.

Sims and Dewald (1982) reviewed the early OWB research results and concluded that they can contribute significantly to beef production and soil conservation in the Southern Great Plains, especially when grown on marginal cropland as forages to complement native rangeland grasses. Forage production potential of OWB monocultures at Woodward, Okla., has been about 4 times greater than well-managed native range in good condition.

Over 700 accessions of OWB's have been assembled at Wood-

Authors are plant physiologists, USDA-ARS, Southern Plains Range Research Station, 2000-18th Street, Woodward, Okla. 73801 . K. Khaleeluddin and L. Bradford are acknowledged for their contributions to the nitrogen analysis, and $A$. Coffey, $S$. Harris, S. Leach, and D. Thompson for their assistance in the field collections and laboratory separations of the plant materials.

Manuscript accepted March 26, 1984. ward, of which approximately 50 are being evaluated for agronomic and beef production performance. This germplasm collection exhibits extreme variability in phenology, morphology, seed production, photosynthetic capacity, and water-use efficiency. The objective of this study was to compare dynamics of aboveground biomass production and partitioning among 4 accessions which differed in forage production relative to soil water availability.

\section{Materials and Methods}

\section{Plant Materials and Culture}

Data were taken from field plots established from seedling transplants in a Hardeman soil (coarse-loamy, mixed thermic typic Ustocrept) in the spring of 1978. The nursery contained 16 Old World bluestem (Bothriochloa spp.) accessions replicated in 8 equal blocks arranged as a randomized complete block design. The plots were fertilized annually with $67 \mathrm{~kg} \mathrm{~N}^{-1}$ as $\mathrm{NH}_{4} \mathrm{NO}_{3}$ in a split application. The nursery was burned each year in March prior to growth initiation. Five rows of 20 plants each on $0.3-$ m centers comprised a plot ( 1 accession/plot).

Four of the 16 accessions were used in this study. These were selected on the basis of their variability in forage production and water-use efficiency. These are identified as WW-758 (B. caucasica (Trin.) C.E. Hubb), WW-604, WW-573, and WW-535 (B. ischaemum var. ischaemum Keng.). WW-758 is 'Caucasian' bluestem. WW-573 was released as 'WW-Spar' bluestem in 1982 (Dewald et al. 1982) WW-604, WW-573, and WW-535 are 3 of 30 yellow bluestem components blended to make 'Plains' bluestem (Taliaferro et al. 1972).

Abbreviations and symbols for all measured, calculated, and derived quantities are defined in Table 1 and are not redefined in the text.

Table. 1. List of abbreviations, symbols, and definitions.

\section{Abbreviations:}

Acc Accession = Old World Bluestems WW-535, WW-573, WW-604, WW-758.

OWB Old World Bluestem

Measured Parameters:

$\mathrm{L}_{\mathrm{A}} \quad$ Leaf blade area $\left(\mathrm{m}^{2}\right.$ plant $\left.^{-1}\right)$

$\mathrm{Nb}$ Leaf blade nitrogen concentration $\left(\mathrm{mg} \mathrm{g}^{-1}\right)$

$t$ Time in days (d)

Wag Aboveground biomass ( $g$ plant ${ }^{1}$ or $g_{~ m^{2}}$ ) $=W b+W s s+W s i$

$\mathrm{Wb}$ Leaf blade biomass ( $\mathrm{g}$ plant ${ }^{-1}$ or $\mathrm{g} \mathrm{m}^{-2}$ )

Wsi Exerted stem and inflorescence biomass ( $\mathrm{g} \mathrm{plant}^{-1}$ or $\mathrm{g} \mathrm{m}^{-2}$ )

Wss Leaf sheath plus enclosed stem biomass ( $\mathrm{g}$ plant ${ }^{-1}$ or $\mathrm{g} \mathrm{m}^{-2}$ )

Calculated Parameters:

ET Evapotranspiration $(\mathrm{mm})=$ net change in soil water $(0$ to $2.6 \mathrm{~m}$ depth) + precipitation

$\mathrm{Lb}$ Leaf blade area index $\left(\mathrm{m}^{2} \mathrm{~m}^{-2}\right)=\mathrm{L}_{\mathrm{A}} / 0.0929 \mathrm{~m}^{2}$ plant $^{-1}$

SLA Specific leaf area $\left(\mathrm{m}^{2} \mathrm{~kg}^{-1}\right)=\left(\mathrm{L}_{\mathrm{A}} / \mathrm{Wb}\right) \times 1000$

WUE Water-use efficiency $\left(\mathrm{g} \mathrm{m}^{-2} \mathrm{~mm}^{-1}\right)=$ Forage production $/ E T$

Derived Growth Parameters (after Hunt and Parsons 1974):

$R \quad$ Relative growth rate of biomass $\left(\mathrm{g} \mathrm{g}^{-1} \mathrm{~d}^{-1}\right)=(1 / \mathrm{Wag})(\mathrm{dWag} / \mathrm{dt})$

$R_{L} \quad$ Relative growth rate of leaf area $\left(\mathrm{m}^{2} \mathrm{~m}^{-2} \mathrm{~d}^{-1}\right)\left(1 / \mathrm{L}_{\mathrm{A}}\right)(\mathrm{dL} / \mathrm{A} / \mathrm{dt})$

$F \quad$ Leaf area ratio $\left(\mathrm{m}^{2} \mathrm{~g}^{-1}\right)=\mathrm{L}_{\mathbf{A}} / \mathrm{Wag}$

E Unit leaf rate $\left(\mathrm{g} \mathrm{m}^{-2} \mathrm{~d}^{-1}\right)=\left(1 / \mathrm{L}_{\mathrm{A}}\right)(\mathrm{dWag} / \mathrm{dt})$

Note: When used as a unit, $d$ is the $S l$ abbreviation for day; when used as a parameter prefix, $d$ means the derivative of the parameter. 
Table 2. Forage (dry matter) production in relation to water use in four Old World bluestem accessions during two growth cycles.'

\begin{tabular}{|c|c|c|c|c|c|c|c|}
\hline \multirow[b]{2}{*}{ Dates (1982) } & \multicolumn{3}{|c|}{ Forage } & \multicolumn{4}{|c|}{ Ave. Temperature } \\
\hline & Acc & production & ET & WUE & Min. & Max. & Total Precip. \\
\hline \multirow{4}{*}{$\begin{array}{l}5 \text { Mar.-6 July } \\
\text { (Cycle 1) }\end{array}$} & & $\left(\mathrm{g} \mathrm{m}^{-2}\right)$ & $(\mathrm{mm})$ & $\left(\mathrm{g} \mathrm{m}^{-2} \mathrm{~mm}^{-1}\right)$ & (C) & (C) & $(\mathrm{mm})$ \\
\hline & WW-535 & $655 a$ & $422 a$ & $1.57 \mathrm{a}$ & 11.7 & 23.5 & 458 \\
\hline & WW-573 & $505 \mathrm{ab}$ & $440 a$ & $1.15 \mathrm{ab}$ & & & \\
\hline & WW-604 & $370 \mathrm{~b}$ & $455 \mathrm{a}$ & $0.81 \mathrm{~b}$ & & & \\
\hline \multirow{5}{*}{$\begin{array}{l}7 \text { July-20 Sept. } \\
\text { (Cycle 2) }\end{array}$} & WW-758 & $686 a$ & $439 a$ & $1.54 \mathrm{a}$ & & & \\
\hline & WW-535 & $248 \mathrm{a}$ & $203 b$ & $1.24 \mathrm{a}$ & 20.1 & 33.5 & 43 \\
\hline & WW-573 & $290 \mathrm{a}$ & $259 \mathrm{a}$ & $1.15 \mathrm{ab}$ & & & \\
\hline & WW-604 & $158 b$ & $197 \mathrm{~b}$ & $0.81 \mathrm{~b}$ & & & \\
\hline & WW-758 & $185 b$ & $228 a b$ & $0.82 b$ & & & \\
\hline
\end{tabular}

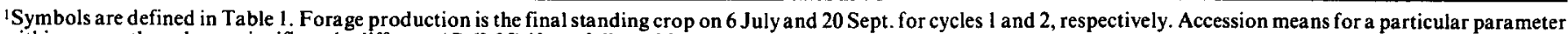
within a growth cycle are significantly different $(P<0.05)$ if not followed by a common letter.

\section{Field Sampling and Laboratory Analysis}

The seasonal course of growth was followed by periodic harvests of randomly chosen subsets of plants throughout 2 growing cycles (spring-summer and summer-fall). Blocks 1 through 4 were used for the spring-summer cycle and blocks 5 through 8 were used for the summer-fall cycle. Sample dates during the first cycle were 19 April; 3, 10, 18, 24 May; 1, 7, 14, 21, 28 June; and 6 July 1982. Four plants/accession/block were sampled on the first 3 days. In order to process the volume of accumulated plant material with the available resources, 2 plants/accession/block were used on the remaining dates. When considering sample size, the apomictic habit and the resulting genetic uniformity within an accession should be emphasized here. During the second growth cycle, 2 plants/accession/block were sampled on 19, 26 July; 2, 9, 30 August; and 20 September 1982.

Neutron moisture probe access tubes were installed to a depth of $3 \mathrm{~m}$ in the center of each plot. Tubes were installed in blocks 1 through 4 (except for WW-535) during March 81 . The remainder of the tubes were installed 15 and 16 March 1982. Soil water content was read on a regular basis by the neutron attenuation method at the mid-point of $0.2-\mathrm{m}$ increments to a depth of $2.6 \mathrm{~m}$.

A random sampling scheme was generated before the start of the experiment that identified plants to be harvested from the center 3 rows of each plot for each succeeding harvest date. Plants were severed at the soil surface to obtain a measure of the aboveground standing crop of biomass. A plant was used only once during the experiment. Blocks 5 through 8 were allowed to grow undisturbed throughout the first cycle. These plots were mowed to a uniform stubble height of $50 \mathrm{~mm}$ on 12 July 1982 prior to initiating the second growth cycle sampling.

The clipped biomass from all plants harvested within a plot was bulked and then separated into leaf blades (severed at the collar), leaf sheaths plus enclosed stems, and exerted stems plus inflorescences (when present). The leaf blade portion of each plot was further subsampled for determination of nitrogen and SLA and the residual leaf blade material, plus the other 2 fractions, were lyophilized to determine dry biomass. The subsamples were sealed in moist plastic bags and kept on ice for 2 to 3 hours until transported to the laboratory. The protein samples were frozen until analyzed.

Leaf area was measured on approximately 20 leaf blades from the SLA subsample by measuring the width of each blade at $10-\mathrm{mm}$ intervals using a measuring magnifier readable to $0.05 \mathrm{~mm}$. The mean width multiplied by the blade length was taken as leaf area. The blade area subset always included all blades from a particular culm so that all leaf ages were presumably represented in the same proportion as their frequency in the plant canopy. The measured blades were lyophilized prior to determining dry weight from which SLA was calculated.

Nitrogen subsamples were lyophilized, ground to pass a $0.6 \mathrm{~mm}$ screen, and analyzed by a modified Hach's Digesdahl $\mathrm{H}_{2} \mathrm{O}_{2}-\mathrm{H}_{2} \mathrm{SO}_{4}$ digestion method. ${ }^{1}$ Bovinc scrum albumin and NBS standard reference material (No. 1573, tomato leaves) were used to calibrate the method.

\section{Data Analysis}

Measured and calculated parameters (Table 1) were subjected to analysis of variance and accession differences were determined by Duncan's multiple range test. Differences in seasonal trends (slopes of parameters vs time) among accessions were examined by combined analysis of regression. Growth parameters (Table 1) were derived using the growth analysis methods and computer program described by Hunt and Parsons (1974). These methods have been fully described more recently by Hunt $(1978,1982)$. The program was translated from ALGOL to BASIC for use in this study. The analysis involves transforming the independent variables (biomass, leaf area) to natural logarithms to increase their homogeneity with time and then expressing them as polynomial functions of time. The functions were fit to the data by stepwise regression (least squares) up to the third order and the $95 \%$ confidence interval calculated for each sample date using the methods of Hunt and Parsons (1974). Overfitting was minimized by selecting the best fit from an analysis of variance table.

IHach Agricultural Division, P.O. Box 907, Ames, IA 50010.

Table 3. Parameter means for four Old World bluestems during two growth cycles.'

\begin{tabular}{|c|c|c|c|c|c|c|c|c|c|c|c|c|}
\hline \multirow{2}{*}{$\begin{array}{l}\text { Dates } \\
(1982)\end{array}$} & \multirow[b]{2}{*}{ Acc } & \multicolumn{4}{|c|}{ Biomass Components } & \multicolumn{3}{|c|}{ Partitioning Coefficients } & \multirow[b]{2}{*}{$\mathrm{Lb}$} & \multirow[b]{2}{*}{$\mathrm{Nb}$} & \multirow[b]{2}{*}{ SLA } & \multirow[b]{2}{*}{$\mathrm{Nb} / \mathrm{SLA}$} \\
\hline & & Wag & $\mathrm{Wb}$ & Wss & Wsi & $\mathrm{Wb} / \mathrm{Wag}$ & Wss/Wag & Wsi/Wag & & & & \\
\hline \multirow{4}{*}{$\begin{array}{l}15 \text { Mar.-6 July } \\
\text { (Cycle 1) }\end{array}$} & & & -18 & $\left.\mathrm{~m}^{-2}\right)$ & & & & & $\left(\mathrm{m}^{2} \mathrm{~m}^{-2}\right)$ & $\left.\mathrm{mg} \mathrm{g}^{-1}\right)$ & $\left(\mathrm{m}^{2} \mathrm{~kg}^{-1}\right)$ & $\left(\mathrm{g} \mathrm{m}^{-2}\right)$ \\
\hline & WW-535 & $255 a b$ & $169 a$ & $83 b$ & $2.7 \mathrm{~b}$ & $0.79 b$ & $0.21 \mathrm{~b}$ & $0.004 b$ & $4.22 \mathrm{a}$ & $18.9 \mathrm{ab}$ & $25.1 \mathrm{~b}$ & $0.74 a^{\prime}$ \\
\hline & WW-573 & $225 \mathrm{~b}$ & $143 a$ & $76 \mathrm{~b}$ & $5.5 \mathrm{a}$ & $0.76 \mathrm{~b}$ & $0.22 \mathrm{~b}$ & $0.013 \mathrm{a}$ & $3.83 a$ & $16.7 c$ & $26.8 \mathrm{a}$ & $0.61 \mathrm{~b}$ \\
\hline & WW-604 & $132 \mathrm{c}$ & $10 \mathrm{lb}$ & $30 \mathrm{c}$ & $1.5 \mathrm{~b}$ & $0.86 \mathrm{a}$ & $0.14 \mathrm{c}$ & $0.004 \mathrm{~b}$ & $2.51 \mathrm{~b}$ & $19.4 a$ & $25.0 \mathrm{~b}$ & $0.76 \mathrm{a}$ \\
\hline \multirow{5}{*}{$\begin{array}{l}7 \text { July-20 Sept } \\
\text { (Cycle 2) }\end{array}$} & WW-758 & $312 a$ & $171 \mathrm{a}$ & $133 a$ & $7.4 \mathrm{a}$ & $0.70 \mathrm{c}$ & $0.28 \mathrm{a}$ & $0.012 \mathrm{a}$ & $4.37 \mathrm{a}$ & $17.4 \mathrm{bc}$ & $26.1 \mathrm{ab}$ & $0.65 b$ \\
\hline & WW-535 & $189 \mathrm{~b}$ & $82 a$ & $107 b$ & $0.1 \mathrm{a}$ & $0.43 a b$ & $0.57 \mathrm{ab}$ & $0.001 \mathrm{~b}$ & $1.90 \mathrm{~b}$ & $14.0 \mathrm{a}$ & $22.5 b$ & $0.62 a$ \\
\hline & WW-573 & $226 a$ & $102 a$ & $124 a$ & $0.1 \mathrm{a}$ & $0.45 a b$ & $0.54 \mathrm{ab}$ & $0.00 \mathrm{lab}$ & $2.73 \mathrm{a}$ & $13.2 \mathrm{a}$ & $26.2 \mathrm{a}$ & $0.50 \mathrm{c}$ \\
\hline & WW-604 & $153 \mathrm{c}$ & $78 \mathrm{ab}$ & $75 \mathrm{c}$ & $0.1 \mathrm{a}$ & $0.50 \mathrm{a}$ & $0.50 \mathrm{~b}$ & $0.001 \mathrm{~b}$ & $1.56 \mathrm{~b}$ & $11.2 \mathrm{~b}$ & $19.5 c$ & $0.57 \mathrm{ab}$ \\
\hline & WW-758 & $119 d$ & $51 b$ & $68 \mathrm{c}$ & $0.2 \mathrm{a}$ & $0.38 \mathrm{~b}$ & $0.62 \mathrm{a}$ & $0.001 \mathrm{a}$ & $1.27 \mathrm{~b}$ & $13.8 \mathrm{a}$ & $25.8 \mathrm{a}$ & $0.52 \mathrm{bc}$ \\
\hline
\end{tabular}

iSymbols are defined in Table 1. Accession means for a particular parameter within a growth cycle are significantly different $(P<0.05)$ if not followed by a common letter. 


\section{Results}

\section{Biomass Production and Partitioning}

Growing conditions varied considerably between the first and second growing cycles. Temperature averaged about $10^{\circ} \mathrm{C}$ higher during the second cycle compared to the first (Table 2). Precipitation during the first cycle was $458 \mathrm{~mm}$ (1.71 of normal), but only 43 $\mathrm{mm}(0.18$ of normal) during the second. All accessions showed visual symptoms of water stress throughout the second cycle and total forage production during this cycle was only 0.4 of first period production. However, the drop in production was not uniform among accessions. Ratios of second period production to first period production were $0.27,0.38,0.43$, and 0.57 for WW-535, WW-604, and WW-573, respectively. These results are consistent with earlier laboratory and field studies (Coyne et al. 1982) which clearly showed WW-573 to be more water-use efficient from both a leaf gas exchange and forage production perspective and to have a greater capacity to maintain production during drought than WW758 or WW-604. However, during periods of ample water, WW758 frequently produces more forage than WW-573 (Coyne et al. 1982).

Soil water use, and hence ET, did not differ among accessions during cycle 1 and only slight differences were observed in cycle 2 (Table 2). When growth began ( $15 \mathrm{March}$ ), the surface $2.6 \mathrm{~m}$ of soil contained 0.28 water by volume. At the transition from cycle 1 to 2 , soil water content was 0.29 , after which it declined linearly to 0.22 (surface $0.4 \mathrm{~m}$ contained $<0.12$ ) by the end of the second cycle.

WUE ranged from $1.6 \mathrm{gm}^{-2} \mathrm{~mm}^{-1}$ in WW-535 to a low of 0.8 in WW-604 during cycle 1 (Table 2). During the dry second cycle, WW-573 and WW-604 continued to produce forage at the same WUE as in cycle 1 , while a 0.21 and 0.47 loss in WUE was observed for WW-535 and WW-758, respectively. Although WW-573 and WW-604 maintained their same average WUE between cycles, WW-573 used significantly more water than WW-604 in the second cycle and used this water with greater efficiency.

Total aboveground biomass and leaf blade area (log transforms, Fig. 1, 2), used to derive the growth analysis parameters, increased

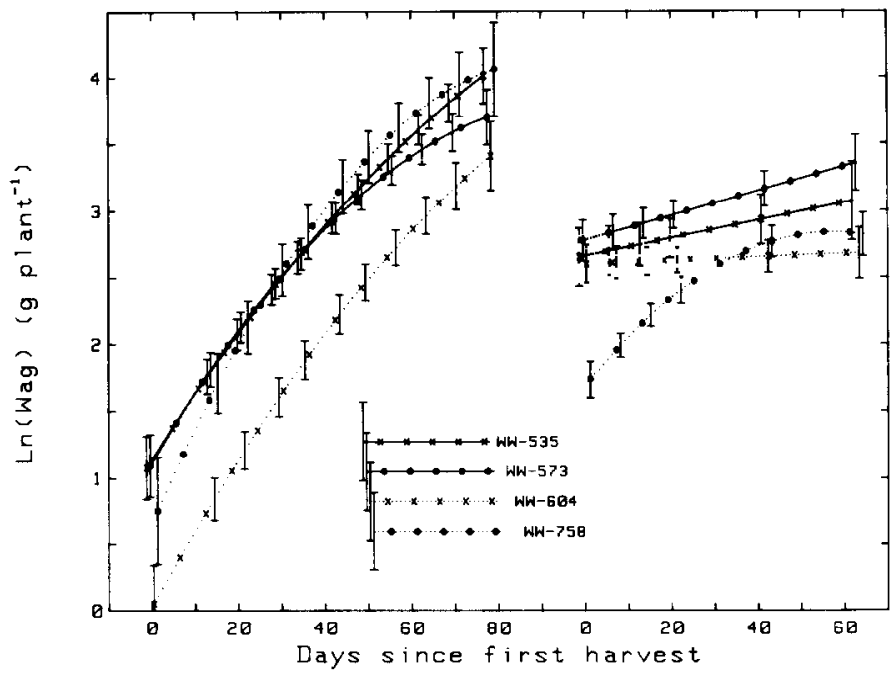

Fig. 1. Seasonal progression of the natural logarithm of total aboveground biomass during a spring-summer (lefi) and summer-fall (right) growth cycle. The 95\% confidence intervals about the regression lines are plotted for each sample date plus or minus 1 or 2 days. Note: The offset was used for clarity in order to show accession differences with dates. Symbols are defined in Table 1. The symbols, " $x$ " and "o" have no significance other than identification of a particular curve with the corresponding accession.

throughout cycle 1 when growing conditions were more favorable. Drought and heat stress during cycle 2 presumably combined to decrease the rate of biomass and leaf area accumulation. Biomass and leaf area accumulation started from a higher base value in cycle 2 than cycle 1 because mowing left the stem bases while

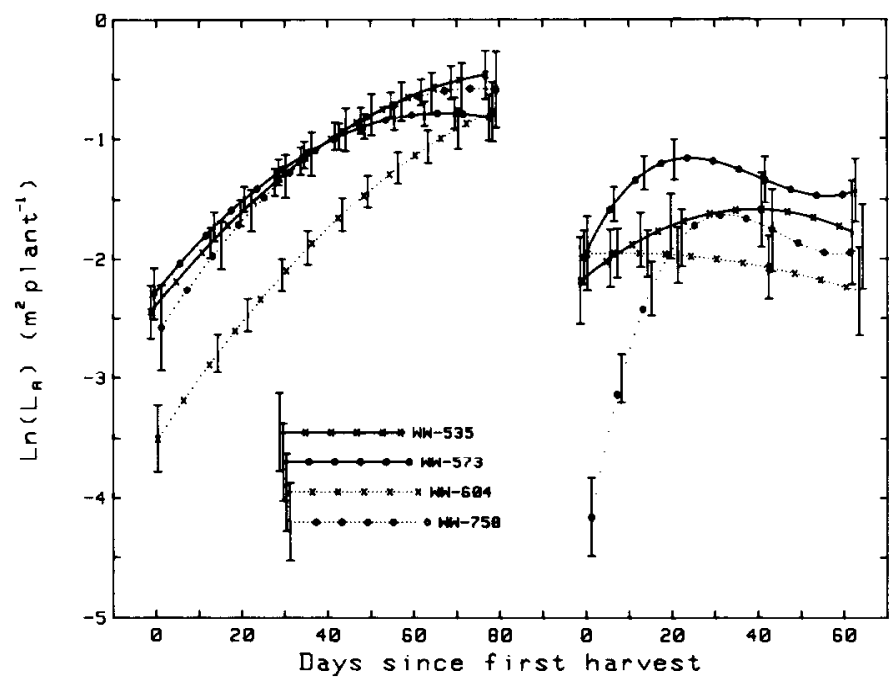

Fig. 2. Seasonal progression of the natural logarithm of leaf blade area during a spring-summer (left) and summer-fall (right) growth cycle. See explanatory note in Fig. I caption.

burning removed all harvestable material. The crown diameter of WW-758 was smaller than in the other accessions, which explains its comparatively low values early in cycle 2 (Fig. 1,2).

The average standing crop of aboveground biomass during each growth cycle and its partitioning among the measured components are compared in Table 3. Slopes of the seasonal responses are given in Table 4. Like total production measured at the end of a cycle (Table 2), the mean values (Wag) based on data from the entire cycle, showed a change in dominance with respect to dry matter production. WW-758 ranked among the highest for Wag during cycle 1 and was the lowest in cycle 2 . WW-573, which was intermediate in mean Wag in cycle 1 , maintained its production level in cycle 2 and ranked the highest among the 4 grasses. WW-604 also maintained performance in cycle 2, but it ranked lowest among the 4 grasses during both cycles. WW-535 was similar to WW-758 in cycle 1, but maintained its production level better under drought stress. The demonstrated superiority of WW-573 for producing forage under suboptimal soil water conditions and the inferiority of WW-758 and WW-604 agrees with previously documented relative differences among these accessions with respect to production potential and leaf WUE (Coyne et al. 1982).

The average rate of biomass accumulation $\left(g_{\text {plant }}^{-1}\right)$ was two-fold greater in WW-758 than in WW-604 (Table 4) for cycle 1 and 15-fold greater in WW-758 and WW-573 than in WW-604 in cycle 2 . The high slope for Wag and SLA in WW-758, during cycle 2 , in spite of its low production, resulted from comparatively small initial values (Fig. 1,2) which in turn were related to smaller crown diameters in this accession compared to the other 3 . The relative influence of crown diameter on the standing crop of biomass and leaf area would be greatest immediately following the mowing that initiated cycle 2 .

Phenology was similar among all 4 of the accessions studied and exposed stems and inflorescences (Wsi) constituted a minor portion of the total biomass. There were some definite differences in the relative proportions of leaf blades and stems plus sheaths as shown by the mean partitioning coefficients (Table 3). WW-758 tended to partition more of Wag to Wss and less to Wb, while WW-604 exhibited the opposite strategy. WW-535 and WW-573 were intermediate and, by the end of the first cycle, Wb and Wss were approximately equal in these 2 accessions. Differences in partitioning were less evident during the second growth cycle after the first 2 sampling dates as the plants approached a more quiescent state due to drought.

\section{Leaf Blade Area and Nitrogen Concentration}

Although WW-604 partitioned a significantly greater proportion of its aboveground biomass to leaf blades during cycle 1 , leaf area index (Lb, Table 3) was significantly less than for the other 3 accessions as a result of its lower production of total biomass. WW-573 was most successful of the three accessions in producing a leafy canopy cond ucive to maximizing light energy capture during the more stressful cycle 2 . Leaf area index increased throughout cycle 1 (Table 4) in all accessions, but increased only through sample date 3 or 4 in the second cycle and then leveled off. In the case of WW-604, Lb actually showed a net decline beyond date 3 of cycle 2 (negative slope, Table 4) as this particular accession appeared to be totally 


\begin{tabular}{|c|c|c|c|c|c|}
\hline \multirow[b]{2}{*}{ Period } & \multirow[b]{2}{*}{ Parameter } & \multicolumn{4}{|c|}{ Accession } \\
\hline & & WW-535 & WW-573 & WW-604 & WW-758 \\
\hline 1 & $\begin{array}{l}\text { Wag } \\
\text { Wb } \\
\text { Wss } \\
\text { Wsi } \\
\text { Wb/Wag } \\
\text { Wss/Wag } \\
\text { Wsi/Wag } \\
\text { Lb } \\
\text { Nb } \\
\text { SLA } \\
\text { Nb/SLA }\end{array}$ & $\begin{array}{c}0.7050 \mathrm{~b} \\
0.3441 \mathrm{a} \\
0.3447 \mathrm{~b} \\
0.0160 \mathrm{c} \\
-0.0069 \mathrm{~b} \\
0.0066 \mathrm{c} \\
0.0003 \mathrm{~b} \\
0.0846 \mathrm{a} \\
-0.3056 \mathrm{~b} \\
-0.0825 \mathrm{ac} \\
-0.0097 \mathrm{~b}\end{array}$ & $\begin{array}{c}0.5387 c \\
0.2134 d \\
0.2952 c \\
0.0301 b \\
-0.0079 c \\
0.0072 b \\
0.0007 a \\
0.0554 b \\
-0.2609 a \\
-0.0969 b c \\
-0.0070 a\end{array}$ & $\begin{array}{r}0.4001 \mathrm{~d} \\
0.2641 \mathrm{c} \\
0.1275 \mathrm{~d} \\
0.0084 \mathrm{~d} \\
-0.0045 \mathrm{a} \\
0.0043 \mathrm{~d} \\
0.0002 \mathrm{~b} \\
0.0672 \mathrm{c} \\
-0.3013 \mathrm{~b} \\
-0.0684 \mathrm{a} \\
-0.0098 \mathrm{~b}\end{array}$ & $\begin{array}{r}0.8396 a \\
0.3084 b \\
0.4918 a \\
0.0394 a \\
-0.0087 d \\
0.0080 a \\
0.0007 a \\
0.0818 a \\
-0.3749 c \\
-0.1041 b \\
-0.1009 c\end{array}$ \\
\hline 2 & $\begin{array}{l}\text { Wag } \\
\text { Wb } \\
\text { Wss } \\
\text { Wsi } \\
\text { Wb/Wag } \\
\text { Wss/Wag } \\
\text { Wsi/Wag } \\
\text { Lb } \\
\text { Nb } \\
\text { SLA } \\
\text { Nb/SLA }\end{array}$ & $\begin{array}{c}0.1108 \mathrm{~b} \\
0.0572 \mathrm{~b} \\
0.0534 \mathrm{~b} \\
0.0001 \mathrm{~d} \\
0.0009 \mathrm{a} \\
-0.0009 \mathrm{c} \\
0.00001 \mathrm{c} \\
0.0073 \mathrm{~b} \\
-0.0292 \mathrm{a} \\
-0.0655 \mathrm{a} \\
0.0006 \mathrm{a}\end{array}$ & $\begin{array}{c}0.1831 \mathrm{a} \\
0.0643 \mathrm{~b} \\
0.1178 \mathrm{a} \\
0.0010 \mathrm{~b} \\
-0.0007 \mathrm{~d} \\
0.0007 \mathrm{~b} \\
0.00003 \mathrm{~b} \\
0.0091 \mathrm{~b} \\
-0.0728 \mathrm{bc} \\
-0.0792 \mathrm{a} \\
0.0014 \mathrm{~b}\end{array}$ & $\begin{array}{c}0.0126 c \\
-0.0245 c \\
0.0367 b \\
0.0004 c \\
-0.0019 c \\
0.0019 a \\
0.00002 b \\
-0.0090 c \\
-0.0443 a c \\
-0.0483 a \\
-0.0010 b\end{array}$ & $\begin{array}{c}0.1876 \mathrm{a} \\
0.1197 \mathrm{a} \\
0.0667 \mathrm{~b} \\
0.0012 \mathrm{a} \\
0.0047 \mathrm{~b} \\
-0.0048 \mathrm{~d} \\
0.00007 \mathrm{a} \\
0.0241 \mathrm{a} \\
-0.1383 \mathrm{~d} \\
-0.1490 \mathrm{~b} \\
-0.0029 \mathrm{c}\end{array}$ \\
\hline
\end{tabular}

ISlope estimates within a row not followed by a common letter are statistically significant $(P<0.05)$. Parameters are defined in Table 1.

quiescent for the remainder of cycle 2 .

Leaf blade nitrogen followed a seasonal trend similar to Lb during both cycles, but accession differences were less pronounced (Table 3). $\mathrm{Nb}$ was highest at the start of cycle $\mathrm{l}$ and averaged about $33 \mathrm{mg} \mathrm{g}^{-1}$ across accessions. WW-573 retained its nitrogen best during cycle 1 , while WW-758 showed the least ability to retain nitrogen as evidenced by the seasonal slopes (Table 4). Although $\mathrm{Nb}$ increased for the first 3 dates of cycle 2, all accessions had a net decline for the entire cycle (Table 4).

The reciprocal of SLA and the ratio Nb/SLA (Table 3) are measures of biomass and nitrogen investment per unit leaf area, respectively. Generally, leaf blades became more expensive in terms of biomass investment and less expensive in terms of nitrogen investment as the season progressed during both cycles (Table 4). During cycle $1, W W-535$ and $W W-604$ produced the most expensive leaves with respect to biomass and nitrogen while WW573 and WW-758 (nitrogen only) invested the least. The drought and heat stress during cycle 2 was associated with further increases in biomass investment by WW-535 and especially WW-604. WW604 also continued to invest more nitrogen per unit leaf area than did WW-573 during this cycle. Differences in strategies that might be derived from the information in Table 3 are that WW- 573 tends to produce a larger number of less costly leaf blades while WW604 , at the other extreme, tends to produce fewer and more costly leaves. WW-535 and WW-758 are intermediate but probably more like WW-573. The strategy of WW-573 would seem most appropriate for maximizing light energy capture in a grazing situation.

\section{Growth Analysis}

The growth analysis parameters permit the production efficiency for new growth to be examined and expressed as a return on invested biomass or leaf area. The relative growth rate of aboveground biomass early in the first growth cycle ranged between 0.05 and $0.07 \mathrm{~g} \mathrm{~g}^{-1} \mathrm{~d}^{-1}$ (Fig. 3). The production efficiency declined linearly through the first cycle to values centering on about 0.02 . During the second cycle, 3 accessions had a constant low rate of return throughout the period, but WW-758 had a trend similar to cycle 1 . W W-758, in both cycles, had an initial relative growth rate that was higher than the other accessions, but also had a steeper rate of decline, so that by the end of the respective growth cycles, the relative growth rate of WW-758 was less than the other accessions. The poor performance of WW-604 is readily seen in the cycle 2 data where $\mathbf{R}$ remained near zero throughout the period.

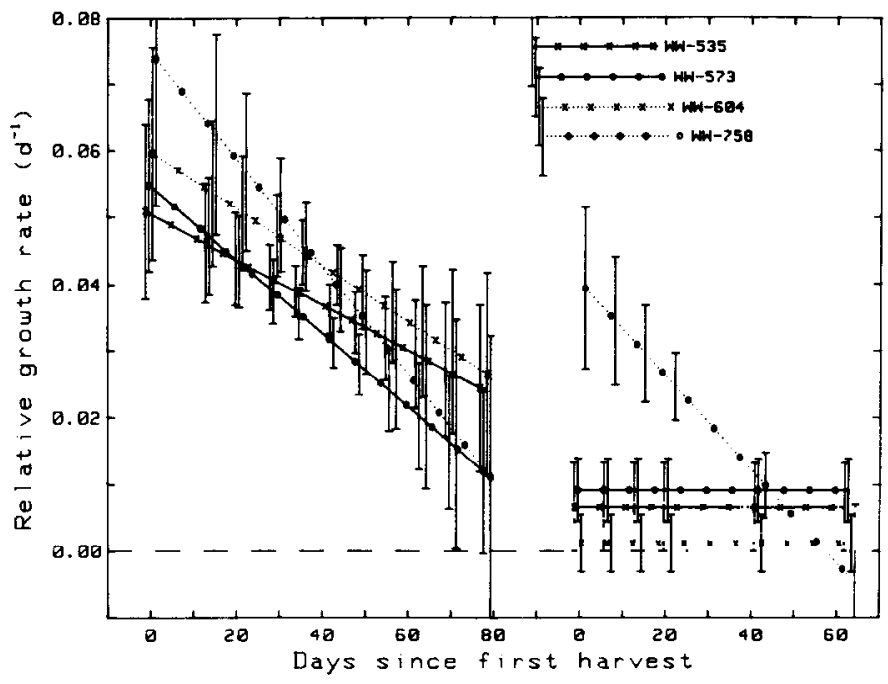

Fig. 3. Changes in relative growth rate of biomass during a spring-summer (left) and summer-fall (right) growth cycle. See explanatory note in Fig. 1 caption.

The relative growth of leaf blade area (Fig. 4) was somewhat different than for biomass. All accessions had similar magnitudes in $R_{L}$ during the first growth cycle and slope differences were less apparent. Like $R, R_{L}$ also declined linearly throughout the first cycle. Conversely, the production of new leaf blade area in relation to existing blade area varied considerably among accessions during cycle 2 . WW-758 and WW-573 apparently were more efficient at supporting new leaf expansion from stored reserves early in cycle 2 than were WW-535 and WW-604, which contributed to the relatively high values of $R_{L}$ for the former at the first harvest. The rapid decline in $R_{L}$ may reflect depletion of reserve pools and the increasing intensity of drought stress, thereby decreasing the efficiency of leaf expansion. $R_{L}$ in all the accessions declined to zero and then 


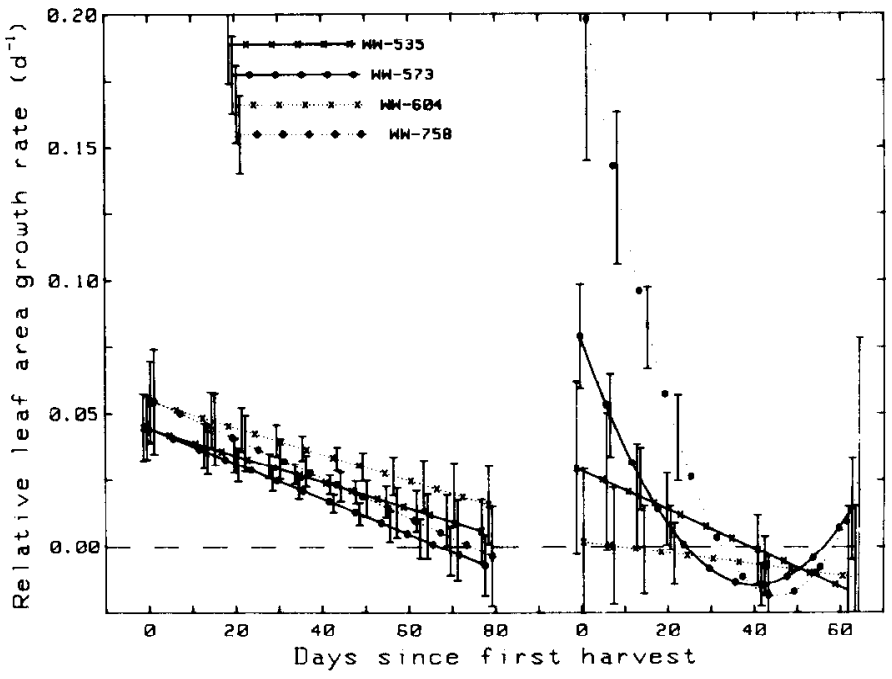

Fig. 4. Changes in relative growth rate of leaf blade area during a springsummer (left) and summer-fall (right) growth cycle. See explanatory note in Fig. 1 caption.

became negative midway through cycle 2 meaning that total leaf blade area actually deceased between successive harvests. The decrease may have resulted from drought effects on leaf expansion or from net export of mobile components to belowground parts. The upturn of $R_{L}$ in WW-573 and WW-758 at the end of the cycle may not be of any real significance. Although the data merited a third order fit of this equation, the values were highly scattered and the confidence limits were large, decreasing the reliability of the trend. Certainly, there was no relief in water stress associated with the upturn.

Relative growth rate can be expressed as a product of leaf area ratio (Fig. 5) and unit leaf rate (Fig. 6), $R=F \times E$. Evans (1972)

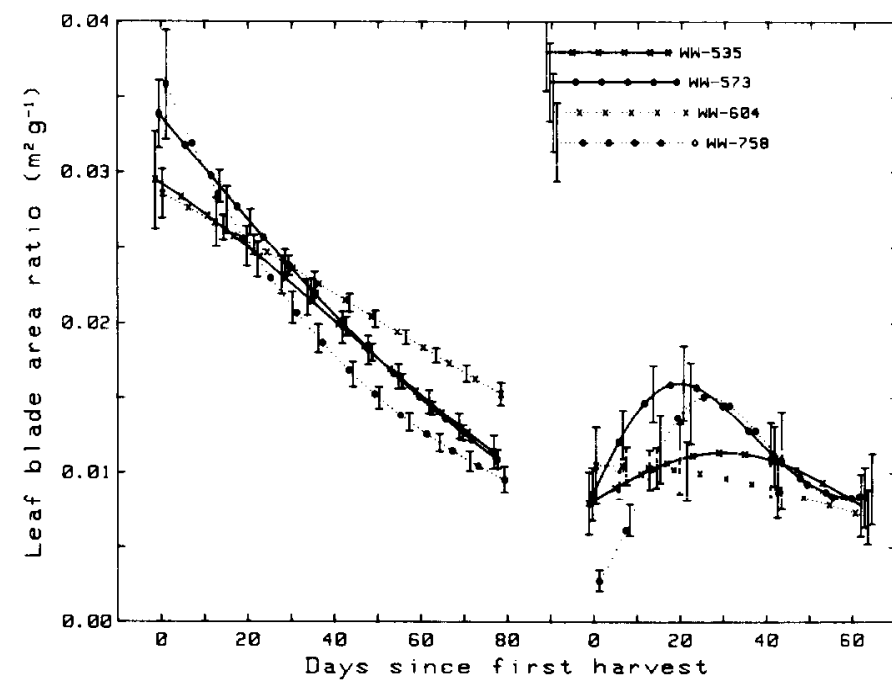

Fig. 5. Changes in leaf area ratio during a spring-summer (left) and summer-fall (right) growth cycle. See explanatory note in Fig. 1 caption.

described $\mathrm{F}$ as a morphological index of plant form and $\mathrm{E}$ as a physiological index related to the photosynthetic activity of the leaves. Each of these indices has its own ontogenetic drift which together make up the drift in $\mathbf{R}$. Partitioning $\mathbf{R}$ into these components allows dry weight increase, resulting primarily from carbon assimilation, to be related to the area of those organs most concerned with carbon assimilation (i.e., the leaves). While photosynthetic capacity in grasses is derived from both leaf blades and leaf sheaths, we have restricted this analysis to the leaf blades because of logistical problems associated with separating the leaf sheaths

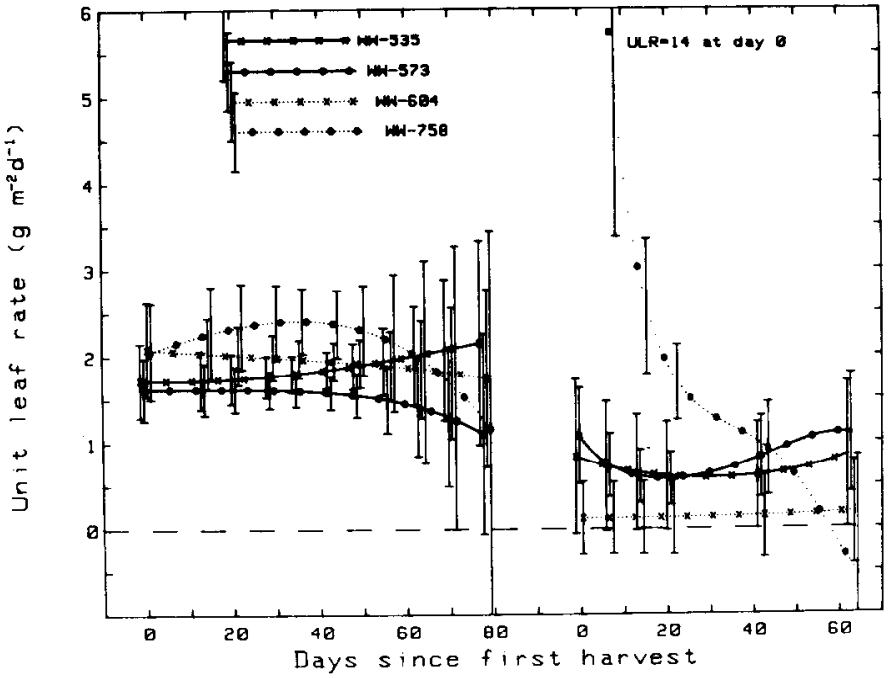

Fig. 6. Changes in unit leaf rate during a spring-summer (left) and summerfall (right) growth cycle. See explanatory note in Fig. 1 caption.

and measuring their area.

Like R, F declined throughout the first cycle (Fig. 5). However, accession differences were more distinct than for $R$. The relative leafiness of WW-604 is clearly seen during the second half of cycle 1 and the high initial value of $F$ for WW-758, followed by a steeper rate of decline, tracks the pattern observed for $R$ and suggests a possible difference in partitioning strategy of these grasses alluded to earlier. Except for initial differences, WW-535 and WW-573 converged on almost identical time trends for $F$ which were intermediate between the extremes of WW-604 and WW-758.

Following defoliation and imposition of drought stress, $F$ behaved much differently (second cycle, Fig. 5). WW-535, WW573, and WW-758 allocated increasing proportions of aboveground biomass to leaf blades during the first 20 to 30 days of the cycle and then $F$ declined for the remainder of this period. Peak values of $F$ were similar for WW-573 and WW-758 although WW-758 started from a much lower value of $F$ and peaked about 1 week later than WW-573. The trend for $F$ in WW-535 peaked one week later than WW-758 and the difference in initial peak values was noticably smaller than in WW-573 and WW-758. Conversely, WW-604 had its highest value for F at the start of the period and declined slightly throughout the second period.

Accession differences in $\mathrm{E}$ occurred primarily during mid-cycle between the extremes of WW-758 and WW-573 (first cycle, Fig. 6). This parameter shows the efficiency of aboveground biomass production in relation to leaf blade area. WW-535 differed from the other accessions in that the leaf blades continued to show an apparent increase in biomass production efficiency throughout the period. WW-573 and WW-604 were essentially flat in trend except for a slight decline in E observed in WW-573 at the end of cycle 1 . Finally, WW-758 increased to a broad peak in the center of the cycle where the return on its leaf area investment exceeded that of the other grasses. However, by the end of the cycle, its efficiency was among the lowest.

The second cycle was more interesting with respect to differences in $\mathrm{E}$ among accessions. Three patterns were observed (Fig. 6). WW-604 had a constant trend in $E$ with a magnitude close to zero. The trends for WW-535 and WW-573 were slightly concave upward centering on approximately $1 \mathrm{~g} \mathrm{~m}^{-2} \mathrm{~d}^{-1}$. In contrast, an extremely high rate of $14 \mathrm{~g} \mathrm{~m}^{-2} \mathrm{~d}^{-1}$ was observed for $W W-758$ at the first harvest date with rates for succeeding dates dropping rapidly throughout the cycle. After 60 days, the rates for WW-758 were among the lowest of 4 accessions. 


\section{Discussion}

A resource optimization strategy that would allow forage plants to capture maximum light energy might consist of attaining maximum leaf number or area with minimum biochemical costs per unit leaf area. Therefore, a plant which has a relatively high leaf area index and specific leaf area combined with relatively low nitrogen content per unit leaf area would conform to this strategy. Caldwell et al. (1981) compared two Agropyron bunchgrasses differing in grazing tolerance and found that the grazing-tolerant species had a lower investment of nitrogen and biomass per unit area of photosynthetic tissues. In this study, the relative degree of conformation to this strategy of resource optimization strategy could be ranked as WW-573>WW-758>WW-535>WW-604.

From a grazing management point of view, the retention of forage quality over time (as estimated by the slope for $\mathrm{Nb}$, Table 4) may be more important to meeting livestock nutritional needs than average nitrogen concentration which may be biased by relatively high values early in the season. WW-573 had the lowest rate of decline in Nb in cycle 1 and WW-758 the highest with WW-535 and WW-604 intermediate. Differences among these accessions with regard to maintenance of leaf nitrogen may be exploitable by proper sequencing of grazing when attempting to design forage systems that are more nearly optimum with respect to matching forage availability and quality with livestock requirements.

The amount of leaf blade area in WW-758 was extremely low compared to the other accessions early in cycle 2 , but especially at the first harvest $(L b=0.2$ for $W W-758$; Mean $L b=1.5$ for $W W-535$, WW-573, WW-604). It is highly improbable that this limited amount of leaf blade area could perform at such a high level of efficiency as $R_{L}$ (Fig. 4) and $E$ (Fig. 6) would seem to suggest. Therefore, we hypothesize that WW-758 was more effective in the accumulation and subsequent mobilization of reserves from the stem bases and/or roots than the other accessions and that the rapid decline in $E$ represents an increasing depletion of these reserve resources and perhaps the intensification of drought stress.

The trends in unit protein rates (based on $\mathrm{Nb} \times 6.25$ ) were similar to unit leaf rates and are not presented in detail here, but these data tend to support the reserve mobilization hypothesis. Unit protein rates for WW-758 averaged $6 \mathrm{~g}$ of aboveground biomass $\mathrm{g}^{-1}$ crude protein $\mathrm{d}^{-1}$ at day 0 of the second cycle, but only 1 $\mathrm{g} \mathrm{g}^{-1} \mathrm{~d}^{-1}$ at the second harvest (day 7). The very rapid decline in both unit leaf and unit protein rates in WW-758 is indicative of small labile carbohydrate and nitrogen reserve pools, which agrees with the conclusions of Caldwell (in press). His detailed synthesis of the published information on labile reserve pools suggests that the absolute pool sizes are small in relation to the diurnal input of carbon as photosynthate. In addition, the contributions of reserves to regrowth of autotrophic tissues following defoliation or stress relief has been overemphasized because reserve levels have generally been expressed as a concentration rather than as quantity per plant. Nevertheless, he points out that reserves must obviously contribute to initial regrowth following severe defoliation, as hypothesized in our study, but that the reserve pools might better be thought of as buffers rather than reservoirs.

The shapes of curves relating $E$ to time are suggestive of reserve use strategies. Eagles (1971) stated that curves which are "U"shaped are indicative of growth based on remobilization of reserves and could include regrowth after defoliation and the commencement of growth after a period of dormancy. In such cases, the initial slope (b) of the curve $\left(R\right.$ or $\left.R_{L}=b-2 c t\right)$ for leaf area (Fig. 4, cycle 2) would be greater than that for biomass (Fig. 3, cycle 2 ), but the rate of decline (c) in the area curve may be greater. This phenomena was observed in all 4 accessions, but was particularly evident in WW-758. Therefore, as Eagles (1971) points out, the initial establishment of leaf area could result in a phase of rapidly declining $E$ followed by a phase of increasing $E$ as the leaves contribute to the overall growth of the plant. These 2 phases can be discerned in the data for WW-535 and WW-573 (Fig. 6, cycle 2), but the magnitude of the decline and subsequent increase in $\mathrm{E}$ is relatively small, probably reflecting drought stress. The failure of WW-758 to increase in E after the rapid decline may indicate lower drought performance potential relative to WW-535 and WW-573.

The general decline in $\mathbf{R}$ (Fig. 3, cycle 1 ) with time was associated with changes in both $F$ and $E$. Simple correlation coefficients between R:F and R:E in the first growth cycle were significant (WW-535, WW-573, WW-604 at $P<0.01$; WW-758 at $P<0.05$ ). Correlation values were higher for $R: F$ average ( $r=0.99)$ than for $R: E$ (average $r=0.86$ ). All correlations for this period were positive except for R: $E$ in WW-535. In this accession, E increased slightly throughout the first cycle (Fig. 6) while $R$ continually decreased. For the second cycle, only WW-758 had a variable $\mathrm{R}$. Correlations for WW-758 (R:F=0.35; R:E=0.75) were not significant.

In a survey of the maximum relative growth rates in controlled, uniform conditions of 132 species of flowering plants (monocots and dicots) from a diversity of habitats, Grime and Hunt (1974) observed a low frequency of potentially fast-growing species in unproductive habitats. They stated that genetic characteristics conducive to rapid growth in productive conditions possibly become disadvantageous when the same plants are subjected to environmental stress. Both this study and a previous one (Coyne et al. 1982), plus several years of comparative field observations on the agronomic characteristics of these grasses, suggest this is truc in the Old World bluestems. For example, WW-758 and WW-604 had the highest $R$ values during cycle 1 (Fig. 3) but the lowest values during the latter part of the cycle 2 when water stress was severe. WW-758 was among the highest forage producers during cycle 1 but had one of the lowest values in cycle 2 as well as the highest percentage reduction between cycles 1 and 2 . Conversely, WW-573, an accession with relatively high water-use efficiency (Coyne et al. 1982) but with a low $\mathrm{R}$ value under more favorable growing conditions, had the least reduction in forage production during cycle 2 as a ratio of cycle 2 to cycle 1 . While WW-535 is in many respects similar to WW-573 in agronomic and physiological characteristics, its water-use efficiency and relative production under stress are apparently more sensitive to environment than these parameters are in WW-573.

\section{Conclusion}

Differences in both water-use efficiency, biomass partitioning, biomass investment per unit leaf area, and maintenance of forage production potential and quality as the soil dried or as the season progressed were observed in 4 Old World bluestems. Accessions having comparatively low values for relative growth rate of biomass may provide a more stable source of forage in the long run. By conserving stored reserves after severe defoliation or during drought stress, these plants may gain an adaptational advantage. This advantage may incorporate a strategy of optimizing leaf production following severe defoliation in a manner that maximizes leaf area but minimizes biomass and nitrogen investment per unit leaf area. Accessions with these characteristics will not necessarily be top performers during periods of favorable growing conditions. However, for managers of forage-livestock production systems attempting to balance livestock numbers with available forage supply, $1,000 \mathrm{~kg} \mathrm{ha}^{-1}$ of extra forage when growing conditions are less than optimal may be of far greater value than $2,000 \mathrm{~kg}$ $\mathrm{ha}^{-1}$ extra forage when growing conditions are more favorable.

\section{Literature Cited}

Caldwell, M.M. (In press). Plant requirements for prudent grazing, p. aa. In Developing Strategies for Rangeland Management. Proc. Nat. Acad. Sci. Forage Allocation Workshop, Albuquerque, New Mexico, 1980. Westview Press, Boulder, Colo.

Caldwell, M.M., J.H. Richards, D.A. Johnson, R.S. Nowak, and R.S. Dzuerec. 1981. Coping with herbivory-photosynthetic capacity and resource allocation in two semiarid Agropyron bunchgrasses. Oecologia 50:14-24 
Celarier, R.P., and J.R. Harlan. 1955. Studies on Old World bluestems. 31 p. Oklahoma Agr. Exp. Sta. Tech. Bull. T-58.

Coyen, P.I., J.A. Bradford, and C.L. Dewald. 1982. Leaf water relations and gas exchange in relation to forage production in four Asiatic bluestems. Crop Science 22:1036-1040.

Dewald, C.L., P.L. Sims, P.I. Coyne, and W.A. Berg. 1982. Notice of release of WW-SPAR bluestem. USDA/ARS and Oklahoma Agr. Exp. Sta.

Eagles, C.F. 1971. Changes in net assimilation rate and leaf area ratio with time in Dactylis glomerata. Ann. Bot. 35:63-74.

Evans, G.C. 1972. The quantitative analysis of plant growth. Studies in Ecology, Vol. 1 Univ. California Press.

Grime, J.P., and R. Hunt. 1975. Relative growth-rate: its range and adaptive significance in a local flora. J. Ecol.. 63:393-422.

Harlan, J.R., M.H. Brooks, D.S. Borgaonkar, and J.M.J. DeWet. 1964. Nature and inheritance of apomixis in Bothriochloa and Dicanthium. Bot. Gaz.. 125:41-46.
Hunt, R. 1978. Plant growth analysis. Studies in Biology, No. 96. Edward Arnold (Publ.) Ltd

Hunt, R. 1982. Plant growth curves. The functional approach to plant growth analysis. University Park Press.

Hunt, R., and I.T. Parsons. 1974. A computer program for deriving growth-functions in plant growth analysis. J. Appl. Ecol. 1 1:297-307.

Sims, P.L., and C.L. Dewald. 1982. Old World bluestems and their forage potential for the Southern Great Plains. A review of early studies. USDA, ARS Agr. Rev. and Manuals, Southern Series, ARM-S-28.

Taliaferro, C.M., J.R. Harlan, and W.L. Richardson. 1972. Plains bluestem. Oklahoma Agr. Exp. Sta. Bull. B-699.

Waller, S.S., and J.K. Lewis. 1979. Occurrence of $C_{3}$ and $C$ photosynthetic pathways in North American grasses. J. Range Manage. 32:12-28. 